\title{
Superendividamento e violência contra a mulher
}

\author{
Indebtedness and violence against women
}

\author{
MARIA Alice COSTA HOFMEISTER ${ }^{a}$
}

\begin{abstract}
RESUMO
O objetivo do presente trabalho é o de analisar a relação entre o superendividamento e a violência contra a mulher. O superendividamento não é idêntico ao simples descumprimento da obrigação, disciplinado nos códigos, mas um fenômeno novo e peculiar, resultante da expansão da oferta do crédito ao consumidor. São muitos os efeitos que o superendividamento gera. Neste artigo, optou-se por enfocar as consequências que ele produz em relação à pessoa do superendividado, do indivíduo afetado, inserido no mundo, em meio às suas relações sociais e familiares. Até que ponto o superendividamento afeta a convivência familiar e conjugal? Quais as alterações que dele decorrem? É o superendividamento um fator da violência praticada contra a mulher? Com o propósito de responder estas perguntas, realizou-se pesquisa de campo, ouvindo as mulheres que sofreram violência, em diferentes contextos, buscando determinar, dentre as diversas motivações das condutas violentas praticadas contra a mulher, o peso a ser atribuido ao superendividamento.
\end{abstract}

Palavras-chave: Superendividamento. Violência contra mulher. Violência doméstica.

\begin{abstract}
The objective of this study is to analyze the relationship between indebtedness and violence against women. The indebtedness is not identical to the obligation simple breach, disciplined in the codes, but a new and peculiar phenomenon, resulting from the expansion of the consumer credit offer. There are many effects that the indebtedness generates. In this article, we chose to focus on the consequences that it produces in relation to the indebtedness person, of the affected individual, inserted in the world, in the midst of its social and family relationships. To what extent the over-indebtedness affects family and conjugal life? What are the changes that result from it? Is the over-indebtedness a factor of violence against women? In order to answer these questions, we carried out a field research, listening to women who have experienced violence in different contexts and to determine, among the various motivations of violent acts committed against women, the weight to be attributed to the over-indebtedness.
\end{abstract}

Keywords: Indebtedness. Violence against women. Domestic violence.

O objetivo do presente trabalho é o de analisar a relação entre o superendividamento e a violência contra a mulher. As razões da escolha de dois fenômenos complexos que aparentam não guardar relação entre si serão a seguir expostas.

O inadimplemento de uma obrigação sempre existiu, constituindo uma preocupação para os juristas e sendo disciplinado pelas leis. O superendividamento, tal como é presenciado no seio da sociedade, com insistência e visibilidade, não é idêntico ao simples descumprimento da obrigação, versado nos códigos, apresentando peculiaridades, aparecendo como um dos efeitos da expansão da oferta do crédito ao consumidor.

Muitas são as consequências decorrentes do superendividamento. Este estudo concentra sua atenção nas pessoas. Encara o superendividado como o indivíduo no contexto das suas relações sociais e familiares. Busca descobrir como a convivência conjugal e familiar são atingidas pela impossibilidade experimentada pelo devedor de pagar as suas dívidas. Entende-se que para além das dívidas impagas, necessário se faz investigar os aspectos pessoais. $\mathrm{O}$

a Professora de Direito Civil da Pontifícia Universidade Católica do Rio Grande do Sul. Advogada. E-mail: <maria.hofmeister@pucrs.br>. 
superendividado está em uma familia e sua situação e seus atos repercutem, alcançando outras pessoas.

Portanto, o artigo preocupa-se não apenas com a pessoa do superendividado, mas com as pessoas que com ele convivem e interagem, do ponto de vista familiar e afetivo. Seguindo tal premissa, o estudo conecta-se com a repersonalização do direito.

Quais os efeitos do superendividamento no seio da família? A conduta do indivíduo superendividado resta alterada na convivência familiar?

Tendo-se presente a violência doméstica praticada contra a mulher, o homem superendividado, sob os efeitos e consequências que se originam dos compromissos contraídos e que ele não logra adimplir, passa a praticar atos de violência contra a esposa, contra a companheira? Ou não haveria relação entre o superendividamento e a violência contra a mulher?

Com o propósito de responder tais questionamentos e de aprofundar a matéria optou-se por realizar pesquisa de campo, ouvindo as vítimas a respeito dos motivos da violência sofrida, buscando aquilatar o peso do superendividamento nas condutas violentas praticadas contra as mulheres.

Foram realizadas 52 entrevistas, no forum de Porto Alegre, no Juizado da Violência Doméstica e Familiar. Os resultados e análise dos dados obtidos encontram-se descritos nas páginas a seguir.

\section{INADIMPLEMENTO E SUPERENDIVIDAMENTO}

O inadimplemento sempre se constituiu em uma possibilidade que poderia ser concretizada na relação obrigacional e como tal uma questão central no direito das obrigações.

Disciplinado no Código Civil, a partir do art. 389, equivale ao descumprimento de uma obrigação contraída. Conforme o artigo em pauta, a inadimplência do devedor acarreta-lhe consequências, responsabilizando-o pelo pagamento de perdas e danos, juros e, ainda, honorários de advogado. É de acrescentar-se, ademais, o componente subjetivo, a culpa, exigido para sujeitar o devedor aos efeitos do inadimplemento. Se o inadimplemento não for imputável ao devedor, e sim, resultante de caso fortuito ou de força maior, o devedor fica dispensado das verbas indenizatórias contempladas no art. 389.

A regra geral do inadimplemento considera-o de um ponto de vista singular, preocupando-se com o obrigado, seja o devedor, seja o credor, que culposamente deixa de adimplir.

A expansão do crédito no mundo e em nosso país gerou situações novas, potencializando-se as situações de descumprimento obrigacional, emergindo um fenômeno que se convencionou chamar de superendividamento.

Segundo relatório da Associação Nacional de Executivos de Finanças, Administrações e Contabilidade (Anefac), o volume de crédito no Brasil aumentou mais de 500\% nos últimos dez anos (junho de 2003 a junho de 2013), representando 55,2\% do Produto Interno Bruto. A concessão de crédito no período examinado passou de $\mathrm{R} \$ 381,3$ bilhões a $\mathrm{R} \$ 2,5$ trilhões. Não obstante tais cifras indicadoras do seu crescimento, assinala-se que ainda há espaço para a expansão do crédito ${ }^{1}$.

Observa-se que a expansão do crédito no Brasil, na última década, particularmente, atingiu as classes C e D, outrora excluídas do mundo do consumo, propiciando a estes consumidores o acesso a bens e serviços. Contudo, a expansão não veio acompanhada da devida informação, a respeito da possibilidade de o consumidor endividar-se acima da sua capacidade real de quitar as dívidas contraídas.

Em si, o crédito não é um mal. A sua expansão e facilitação na atualidade é que preocupam os especialistas. Bruno Miragem assinala que ocorreu um avanço, pois o consumidor teve e está tendo acesso aos bens de consumo, os quais, de outra maneira, não poderiam ser adquiridos, reconhecendo que "a massificação do crédito foi um dos grandes elementos de promoção da economia no último século"'.

Mas, em sua análise percuciente, Miragem detecta alguns problemas. $\mathrm{O}$ oferecimento do crédito, observa o autor, aparece com duas características. Não se exigem maiores garantias e não se observam os limites de endividamento pessoal do tomador ou mesmo o seu padrão de renda. Consequentemente, as taxas de juros são mais elevadas, devido ao risco assumido pelo credor $^{3}$.

Do ponto de vista do direito do consumidor, dois aspectos hão de ser destacados. O primeiro reside em reconhecer-se o agravamento da vulnerabilidade do consumidor, tomador de crédito, quando a sua necessidade de obter recursos financeiros leva-o a submeter-se a condições contratuais caracterizadas pela extrema onerosidade. $\mathrm{O}$ segundo aspecto encontra-se no estímulo ao superendividamento dos consumidores de crédito, com a impossibilidade de pagar as dívidas contraídas de boa-fé, decorrentes de um planejamento financeiro inadequado, ou mesmo de circunstâncias imprevistas, como o desemprego a doença ou morte, os divórcios, dentre outros ${ }^{4}$.

Como enfrentar tal questão, uma vez que consumo e crédito estão interligados, é um desafio que se põe hoje aos juristas. A Constituição Federal, ao tratar dos 
princípios gerais da atividade econômica, determinou que a ordem econômica tem por fim assegurar a todos existência digna, consoante os ditames da justiça social (art. 170). Um dos princípios a serem observados é o da defesa do consumidor (art. 170, inciso V). Assim, infere Marília de Ávila e Silva Sampaio: "sob a ótica de proteção da dignidade da pessoa humana é que se deve desenvolver a análise da proteção ao consumidor superendividado"s.

Se é irrefutável que o consumidor é vulnerável, evidente por outro lado, que não há sociedade de consumo sem crédito, e o crédito é necessário ao desenvolvimento do país, como assinala o Ministro Herman Benjamim, do Superior Tribunal de Justiça. Reconhece, todavia, a autoridade que não é interessante para os bancos a existência de consumidores incapazes de pagar suas dívidas, tornando-se possível "estabelecer um meio-termo entre a liberdade de crédito e regras que estimulem o consumo responsável"'6.

Parece então que se trata de estabelecer regras que protejam o consumidor, admitindo-se a necessidade de oferecer crédito, estimulando-se o consumo responsável.

\section{SUPERENDIVIDAMENTO}

A lição de Cláudia Lima Marques, tantas vezes mencionada, após enfatizar que o consumo e o crédito são faces de uma mesma moeda, presentes nos sistemas econômico e jurídico de países, tanto desenvolvidos como emergentes, esclarece:

O superendividamento pode ser definido como a impossibilidade global de o devedor pessoa física, consumidor, leigo e de boa-fé, pagar todas as suas dívidas atuais e futuras de consumo (excluídas as dívidas com o Fisco, oriundas de delitos e de alimentos) $)^{7}$.

\section{Adverte a autora:}

Este estado é um fenômeno social e jurídico a necessitar algum tipo de saída ou solução pe lo direito do consumidor, a exemplo do que aconteceu com a falência e a concordata no direito da empresa, seja por meio de parcelamento, prazos de graça, redução dos montantes, dos juros, das taxas, seja por todas ou quase todas as demais soluções possíveis para que possa pagar ou adimplir todas ou quase todas as suas dívidas em face de todos os credores, fortes e fracos, com garantias ou não .

A doutrina corrente identifica duas modalidades de superendividamento: passivo e ativo. No superendividamento passivo, o consumidor é levado a contrair as dívidas em razão de infortúnios, ou seja, não contribuiu para a crise, mas viu-se envolvido pelo desemprego ou por doenças, acidentes, morte, nascimento de filho, dentre outras hipóteses), buscando saída no crédito oferecido. No caso do superendividamento ativo, o consumidor tem um comportamento abusivo, consome sem o planejamento adequado e além das suas possibilidades, ao arrepio do seu orçamento 9 .

\section{SUPERENDIVIDADOS}

Existem consequências pessoais e familiares para o indivíduo superendividado que não podem ser ignoradas.

Quando o consumidor não consegue cumprir os compromissos assumidos, não apenas ele sofre com o fato, mas os membros da família têm a sua vida perturbada.

Efeitos perversos do superendividamento são assinalados pelos autores dedicados ao tema, dentre eles Clarissa Costa de Lima e Karen Danilevicz Bortoncello ${ }^{10}$. Leiam-se abaixo as observações das autoras:

... o endividamento assume uma dimensão patológica, com repercussões econômicas, sociais, psicológicas e até médicas, quando o rendimento familiar não é mais capaz de suportar o cumprimento dos compromissos financeiros.

As potenciais consequências geradas com a submissão ao superendividamento familiar podem ser identificadas pela repercussão nos procedimentos de violência doméstica, pelos procedimentos de apuração de ato infracional e até mesmo nas dificuldades em solucionar a partilha de bens quando da separação/divórcio do casal...

André Schmidt Neto, no mesmo sentido, também menciona que dramas psicológico-emocionais, familiares e sociais podem conduzir o endividado ao alcoolismo e, em casos mais extremos, ao suicídio. Destaca, ademais, a associação superendividamento e criminalidade, pois o desejo pelos objetos consumíveis, no contexto de uma sociedade desigual, gera a onda de crimes que ora se presencia ${ }^{11}$.

Consigna Marília de Ávila e Silva Sampaio a situação de verdadeira exclusão social vivida pelo superendividado, atingindo o padrão de dignidade do próprio devedor e da sua família, concluindo que a abordagem do superendividamento, sob o ponto de vista jurídico, possibilita a inclusão social do devedor, 
com sua reinserção no mercado de consumo e na sociedade, de maneira digna ${ }^{12}$.

Relevante referir neste escrito, como ponto de partida para o tema e objetivos do presente artigo, o relatório intitulado Desemprego e sobreendividamento: contornos de uma "ligação perigosa", concluído em março de 2006, pela equipe de investigadores do Observatório do Endividamento dos Consumidores, do Centro de Estudos Sociais da Universidade de Coimbra, reproduzido por Catarina Frade e Sara Magalhães ${ }^{13}$.

O trabalho levado a cabo em Portugal esboçou os valores, atitudes e comportamentos dominantes dos superendividados, bem como as estratégias de enfrentamento (soluções adotadas pelos consumidores para ultrapassar o impasse financeiro).

Destacam-se, resumidamente, alguns dos pontos significativos da análise empreendida.

No que respeita aos valores, atitudes e comportamentos dos sobreendividados ${ }^{14}$, estes acham-se inseridos num estilo de vida predominantemente urbano, com acentuada acessibilidade a bens e serviços bem como expostos a uma forte pressão social para adquiri-los. As formas de financiamento são múltiplas. À disposição dos mesmos encontram-se os cartões de débito e crédito, cartões de lojas, créditos pessoais, crédito à habitação, crédito automóvel e outros.

Os contatos permitiram observar nos entrevistados uma "enorme confusão" acompanhada de "falta de clareza discursiva", de "apatia na voz e nos movimentos, o choro frequente e uma expressão de cansaço e desânimo"15.

Os indivíduos ouvidos demonstraram fragilidade emocional, oscilando entre o sentimento de desalento e a esperança de recuperar a situação de normalidade. Ao relatar as contratações, expressavam-se com dificuldade de precisar datas e valores, apresentando os acontecimentos de maneira desestruturada, distante e vaga ${ }^{16}$.

A pesquisa detectou, por outro lado, que os sobreendividados ostentavam um sentimento de culpa e de vergonha em relação aos seus filhos. Sentiamse fracassados na liderança da vida familiar atingida em seu equilíbrio e estabilidade. No enfrentamento da situação, buscavam preservar os filhos, preferindo sacrificar seus hábitos próprios de consumo do que submeter a prole a uma diminuição de seus padrões de consumo ${ }^{17}$.

A vergonha dos sobreendividados não se manifesta somente no âmbito familiar. Ampliando-se o espectro das relações sociais, o comportamento perante terceiros vem movido por tal sentimento. Sentem-se inibidos e tentam esconder suas fraquezas perante terceiros. O comportamento que predomina é o do afastamento social. Em alguns casos, resulta da consciência das limitações financeiras que impedem a manutenção dos padrões de lazer anteriores, enquanto em outros casos, o afastamento resulta de um estado emocional deliberado, pois o indivíduo rejeita a vida em grupo, optando pelo isolamento ${ }^{18}$.

À teia complexa dos sentimentos evidenciados, soma-se a revolta pela falta de apoio de caráter institucional em relação às soluções costumeiramente oferecidas aos devedores coletivos, grupos socioeconômicos, imigrantes e minorias étnicas ${ }^{19}$.

Sobreendividados são portadores de baixa autoestima. Não acreditam em si, nas suas capacidades profissionais e relacionais. Em relação à vida conjugal, alguns confessam um "aumento da conflitualidade entre o casal" enquanto outros admitem um afastamento emocional do outro ${ }^{20}$.

Christian de Montlibert descreve o viver superendividado, apontando a angústia e o ressentimento, ligados às dificuldades materiais, em vários aspectos ligados ao padrão desfrutado: alimentação, bens materiais diversos, como aparelhos eletrônicos, móveis, eletricidade (cortes de telefone e de eletricidade). Ainda de registrar-se outros infortúnios como a impossibilidade de manter a residência, o fracasso profissional, a dependência da família ou de instituições. Por vezes, os casais se separam e se mudam para dificultar o trabalho dos oficiais de justiça ${ }^{21}$.

Levantamento recente, realizado por entidades de defesa do consumidor e divulgado pela Proteste (Associação Brasileira de Defesa do Consumidor), noticiado em periódico gaúcho ${ }^{22}$, indicou que os brasileiros têm a saúde mais abalada por problemas financeiros do que os europeus que passam por uma crise econômica. A conclusão baseia-se em 818 entrevistas realizadas com brasileiros. Na Europa, os países pesquisados foram Portugal, Espanha, Itália e Bélgica. O total de indivíduos ouvidos foi de 8.507 pessoas. Os males apontados foram a ansiedade (32\% dos brasileiros, seguidos pelos portugueses $(25 \%)$, espanhóis $(24 \%)$, italianos $(21 \%)$ e belgas (12\%), insônia (brasileiros, $24 \%$, portugueses, $17 \%$, espanhóis, $21 \%$, italianos, $13 \%$ e belgas $11 \%$ ), irritação (brasileiros, $24 \%$, portugueses, $21 \%$, espanhóis, $22 \%$, italianos, $18 \%$ e belgas $11 \%$ ) e, por fim, dor de cabeça (brasileiro, $17 \%$, portugueses, $13 \%$, espanhóis, $17 \%$, italianos, $10 \%$ e belgas, $5 \%$ ). Como se pode constatar, os superendividados brasileiros lideram em todos os itens, perdendo somente para Portugal no que respeita ao uso de medicamentos.

Infere-se, pois, que são muitas as consequências do superendividamento que atingem o consumidor individual e socialmente, em sua vida pessoal, familiar, 
profissional e social. Dentre tantas, selecionouse a questão da violência doméstica, buscando-se resposta para a seguinte pergunta: Qual a relação entre superendividamento e violência contra a mulher? O superendividamento é causa da violência contra a mulher? O indivíduo superendividado agride mais?

\section{A VIOLÊNCIA CONTRA MULHER}

Não obstante as conquistas femininas no terreno social, jurídico e político, o reconhecimento constitucional da igualdade entre os sexos, a violência contra a mulher ainda hoje é uma realidade preocupante, no mundo e em nosso país.

Com o objetivo de investigar a violência contra a mulher no Brasil e de apurar denúncias de omissão por parte do poder público no que tange à aplicação de instrumentos legais para proteger as mulheres em situação de violência, foi instituída Comissão Parlamentar Mista de Inquérito, cujo relatório final foi divulgado em junho de 2013.

Em sua apresentação, o texto enfatiza que a superação da violência, em suas diversas formas, constitui-se num dos maiores desafios para o Estado brasileiro porquanto a violência e o feminicídio configuram violações aos direitos humanos das mulheres e como tal fatos incompatíveis com o Estado Democrático de Direito.

A peça assinala "a ausência de dados estatísticos confiáveis e comparáveis em todos os poderes constituídos e em todas esferas de governo"23. Conclui, portanto, por detectar uma "necessidade urgente de criar sistemas de informações sobre a violência contra as mulheres que permitam planejar, monitorar e avaliar as políticas públicas" ${ }^{24}$.

Segundo o documento acima mencionado, o Rio Grande do Sul, cuja população é de 10.695.532 (IBGE, Censo de 2010), e a população feminina alcança 5.489.827 (IBGE, Censo de 2010), ocupa o 19 lugar em assassinatos de mulheres, com a taxa de 4,1 homicídios femininos por 100 mil mulheres (CEBELA. Mapa da Violência 2012).

Neste contexto, a necessidade de enfrentar a dura realidade trouxe o aparecimento da legislação especial, precisamente a Lei n. 11.340/06, denominada " Lei Maria da Penha".

O diploma legal expressa o seu objetivo no art. $1^{\circ}$, o de criar mecanismos para coibir e prevenir a violência doméstica e familiar contra a mulher, nos termos da Constituição Federal, de convenções e tratados internacionais ratificados pelo Brasil. Para tanto, prevê a criação dos Juizados de Violência Doméstica e estabelece medidas de assistência e proteção às mulheres em situação de violência doméstica e familiar.

A violência doméstica e familiar contra a mulher compreende "qualquer ação ou omissão baseada no gênero que lhe cause morte, lesão, sofrimento físico, sexual ou psicológico e damo moral ou patrimonial" (art. 5으. ). Os eventos lesivos podem ocorrer no âmbito da unidade doméstica, no âmbito da família e em qualquer relação íntima de afeto, ampliando-se aqui o espectro de possibilidades, pois o agressor pode ser alguém que conviva ou tenha convivido com a ofendida, independentemente de coabitação (art. $5^{\circ}$ I, II e III).

Importante destacar o reconhecimento explícito que realiza a lei: a violência contra a mulher, quer doméstica, quer familiar, constitui uma forma de violação dos direitos humanos (art. $6^{\circ}$ ).

A lei define cinco formas de violência: física, psicológica, sexual, patrimonial e moral (art. 7º, incisos I a V).

A responsabilidade pela concretização dos objetivos da lei, o combate à violência doméstica e familiar incumbe à União, aos Estados, ao Distrito Federal e aos Municípios (ações governamentais) e à sociedade (ações não governamentais), consoante diretrizes especificadas (art. $8^{\circ}$ ).

No que respeita ao atendimento da ofendida, este será desencadeado pela ocorrência policial, contemplando-se no art. 11 várias providências a cargo da autoridade. Dentre as medidas, está o dever de remeter no prazo de 48 (quarenta e oito) horas expediente apartado ao juiz com o pedido da ofendida para a concessão de medidas protetivas de urgência. O juiz, ao receber o pedido da vítima, decide sobre a concessão das medidas.

Enquanto isso, na esfera policial, desdobram-se os procedimentos (art. 12), culminando com a conclusão do inquérito policial, a ser remetido ao juiz e ao Ministério Público.

$\mathrm{O}$ elenco de medidas protetivas de urgência que obrigam o agressor é amplo, podendo ser aplicadas em conjunto ou separadamente (a enumeração do art. 22 é exemplificativa, porque admite que outras poderão ser aplicadas): suspensão da posse ou restrição do porte de armas, com comunicação ao órgão competente; afastamento do lar, domicílio ou local de convivência com a ofendida; proibição de determinadas condutas, dentre as quais: a) aproximação da ofendida de seus familiares e das testemunhas, fixando-se o limite mínimo de distância entre estes e o ofensor; contato com a ofendida, seus familiares e testemunhas, por qualquer meio de comunicação; frequentação de determinados lugares a fim de preservar a integridade física e psicológica da ofendida; restrição ou suspensão 
de visitas aos dependentes menores, ouvida a equipe de atendimento multidisciplinar ou serviço similar; prestação de alimentos provisionais ou provisórios.

\section{A PESQUISA}

Com o intuito de responder às questões anteriormente postas, as quais motivaram o trabalho, decidiu-se por realizar pesquisa de campo $^{25}$. O superendividamento guarda relação específica com a violência de gênero? A hipótese a ser verificada estava assim formulada: o superendividamento é causa de violência contra a mulher. $O$ superendividamento atinge o relacionamento familiar, ocasionando um aumento da violência. A proposição era de ser verificada ${ }^{26}$.

A cidade de Porto Alegre conta com o Juizado da Violência Doméstica e Familiar contra a Mulher, no qual atuam quatro juízes, sendo o único especializado, para onde convergem todos os processos da capital que digam respeito à Lei Maria da Penha.

Esta pesquisadora teve a oportunidade de ouvir os juízes que atuam no Juizado, a psicóloga, o assistente social e as vítimas.

Foram no total 52 entrevistas com as vítimas, todas realizadas após as audiências, no período compreendido entre 28 de agosto e 02 de outubro de 2013. Elas haviam recebido medida protetiva e eram ouvidas em audiência, sendo que algumas foram prorrogadas e outras encerradas. As vítimas responderam oralmente o questionário ${ }^{27}$ que lhes foi apresentado pela pesquisadora. Os dados constantes do questionário, e que deveriam ser respondidos pelas entrevistadas, foram os seguintes:

1. Nome (poderia ser fictício)

2. Idade

3. Estado civil

4. Cor

5. Naturalidade

6. Atividade profissional e escolaridade

7. Renda mensal

8. Agressor (marido, companheiro, etc.)

9. Tipo de violência

10. Quantas vezes sofreu violência e há quanto tempo

11. Ocupação do agressor e escolaridade

12. Renda do agressor

13. Motivo da agressão

14. Situação financeira da família à época da agressão

15. Se o agressor estava afetado pela situação financeira e como era o ambiente no lar

16. Na opinião da entrevistada, qual a relevância do fator financeiro na violência sofrida.
Analisados e agrupados os resultados, chegou-se à análise descritiva que vai a seguir reproduzida:

Idade

\begin{tabular}{llcc}
\hline & Frequência & Porcentual \\
\hline \multirow{6}{*}{ Válido } & Até 20 anos & 5 & 9,6 \\
& 21 a 30 anos & 15 & 28,8 \\
& 31 a 40 anos & 26 & 50,0 \\
& 41 a 50 anos & 5 & 9,6 \\
& Acima de 51 anos & 1 & 1,9 \\
& Total & 52 & 100,0 \\
\hline
\end{tabular}

Estado Civil

\begin{tabular}{llcc}
\hline & & Frequência & Porcentual \\
\hline \multirow{7}{*}{ Válido } & solteiro & 43 & 82,7 \\
& casado & 3 & 5,8 \\
& unido(a) estavelmente & 1 & 1,9 \\
& separado & 1 & 1,9 \\
& divorciado & 4 & 7,7 \\
& Total & 52 & 100,0 \\
\hline
\end{tabular}

Cor

\begin{tabular}{clcc}
\hline & & Frequência & Porcentual \\
\hline \multirow{6}{*}{ Válido } & Branco & 34 & 65,4 \\
& Negro & 13 & 25,0 \\
& Pardo & 5 & 9,6 \\
& Total & 52 & 100,0 \\
\hline
\end{tabular}

Natural de onde

\begin{tabular}{llcc}
\hline & & Frequência & Porcentual \\
\hline \multirow{4}{*}{ Válido } & Porto Alegre & 38 & 73,1 \\
& Interior do RS & 12 & 23,1 \\
& Outros Estados & 2 & 3,8 \\
& Total & 52 & 100,0 \\
\hline
\end{tabular}

Escolaridade da vítima

\begin{tabular}{llcc}
\hline & Frequência & Porcentual \\
\hline & Fundamental Incompleto & 9 & 17,3 \\
& Fundamental Completo & 9 & 17,3 \\
& Ensino Médio Incompleto & 8 & 15,4 \\
Válido & Ensino Médio Completo & 20 & 38,5 \\
& Superior Incompleto & 4 & 7,7 \\
& Superior Completo & 2 & 3,8 \\
& Total & 52 & 100,0 \\
\hline
\end{tabular}

Renda Mensal da vítima

\begin{tabular}{llcc}
\hline & & Frequência & Porcentual \\
\hline & Até $\mathrm{R} \$ 800,00$ & 22 & 42,3 \\
& $\mathrm{R} \$ 801,00-\mathrm{R} \$ 1.200,00$ & 14 & 26,9 \\
& $\mathrm{R} \$ 1.201,00-\mathrm{R} \$ 1.600,00$ & 3 & 5,8 \\
Válido & $\mathrm{R} \$ 1.601,00-\mathrm{R} \$ 2.000,00$ & 4 & 7,7 \\
& Acima de $\mathrm{R} \$ 2.001,00$ & 2 & 3,8 \\
& Sem renda própria & 7 & 13,5 \\
& Total & 52 & 100,0 \\
\hline
\end{tabular}


Agressor

\begin{tabular}{llcc}
\hline & & Frequência & Porcentual \\
\hline \multirow{4}{*}{ Válido } & Marido & 4 & 7,7 \\
& Companheiro & 34 & 65,4 \\
& Ex companheiro & 9 & 17,3 \\
& Namorado & 5 & 9,6 \\
& Total & 52 & 100,0 \\
\hline
\end{tabular}

Idade Agressor

\begin{tabular}{llcc}
\hline & & Frequência & Porcentual \\
\hline \multirow{6}{*}{ Válido } & 1 & 1,9 \\
& Até 20 anos & 16 & 30,8 \\
& 21 a 30 anos & 16 & 30,8 \\
& 31 a 40 anos & 16 & 26,9 \\
& 41 a 50 anos & 5 & 9,6 \\
& Acima de 51 anos & 52 & 100,0 \\
\hline
\end{tabular}

Escolaridade Agressor

\begin{tabular}{llcc}
\hline & Frequência & Porcentual \\
\hline \multirow{4}{*}{ Válido } & Fundamental Incompleto & 19 & 36,5 \\
& Fundamental completo & 10 & 19,2 \\
& Ensino Médio Incompleto & 3 & 5,8 \\
& Ensino Médio Completo & 15 & 28,8 \\
& Superior Incompleto & 4 & 7,7 \\
& Superior Completo & 1 & 1,9 \\
Total & 52 & 100,0 \\
\hline
\end{tabular}

\section{Tipo de Violência}

\begin{tabular}{llcc}
\hline & & Frequência & Porcentual \\
\hline \multirow{4}{*}{ Válido } & Física & 6 & 11,5 \\
& Psicológica & 16 & 30,8 \\
& Física e Psicológica & 30 & 57,7 \\
& Total & 52 & 100,0 \\
\hline
\end{tabular}

\section{Quantas vezes sofreu violência}

\begin{tabular}{llcc}
\hline & & Frequência & Porcentual \\
\hline \multirow{6}{*}{ Válido } & 16 & 30,8 \\
& 4-3 vezes & 9 & 17,3 \\
& $7-10$ vezes & 11 & 21,2 \\
& Mais de 11 vezes & 16 & 30,8 \\
& Total & 52 & 100,0 \\
\hline
\end{tabular}

Há quanto tempo

\begin{tabular}{llcc}
\hline & & Frequência & Porcentual \\
\hline \multirow{6}{*}{ Válido } & Até 6 meses & 11 & 21,2 \\
& $7-12$ meses & 12 & 23,1 \\
& $13-18$ meses & 1 & 1,9 \\
& $19-24$ meses & 8 & 15,4 \\
& Mais de 25 meses & 20 & 38,5 \\
& Total & 52 & 100,0 \\
\hline
\end{tabular}

Renda do agressor

\begin{tabular}{llcc}
\hline & & Frequência & Porcentual \\
\hline & Até $\mathrm{R} \$ 800,00$ & 4 & 7,7 \\
& $\mathrm{R} \$ 801,00-\mathrm{R} \$ 1.200,00$ & 14 & 26,9 \\
& $\mathrm{R} \$ 1.201,00-\mathrm{R} \$ 1.600,00$ & 4 & 7,7 \\
Válido & $\mathrm{R} \$ 1.601,00-\mathrm{R} \$ 2.000,00$ & 6 & 11,5 \\
& Acima de $\mathrm{R} \$ 2.001,00$ & 11 & 21,2 \\
& Não sabe & 13 & 25,0 \\
& Total & 52 & 100,0 \\
\hline
\end{tabular}

Motivo da agressão

\begin{tabular}{llcc}
\hline & & Frequência & Porcentual \\
\hline \multirow{4}{*}{ Válido } & Álcool & 14 & 26,9 \\
& Conflitos conjugais & 29 & 55,8 \\
& Outras drogas & 9 & 17,3 \\
& Total & 52 & 100,0 \\
\hline
\end{tabular}

Situação financeira da família na época da agressão

\begin{tabular}{clcc}
\hline & & Frequência & Porcentual \\
\hline \multirow{4}{*}{ Válido } & Ótima & 1 & 1,9 \\
& Boa & 24 & 46,2 \\
& Regular & 22 & 42,3 \\
& Ruim & 5 & 9,6 \\
& Total & 52 & 100,0 \\
\hline
\end{tabular}

O agressor estava afetado pela situação financeira?

\begin{tabular}{clcc}
\hline & & Frequência & Porcentual \\
\hline \multirow{2}{*}{ Válido } & Sim & 11 & 21,2 \\
& Não & 41 & 78,8 \\
& Total & 52 & 100,0 \\
\hline
\end{tabular}

Atividade Profissional da vítima

\begin{tabular}{lcc}
\hline & Frequência & Porcentual \\
\hline Aposentada & 1 & 1,9 \\
Atendente & 1 & 1,9 \\
Atendente Loja & 1 & 1,9 \\
Auxiliar Administrativo & 2 & 3,8 \\
Auxiliar arquivo & 1 & 1,9 \\
Auxiliar cozinha & 1 & 1,9 \\
Auxiliar de higienização & 1 & 1,9 \\
Auxiliar Produção & 1 & 1,9 \\
Auxiliar Serviços Gerais & 1 & 1,9 \\
Balconista & 2 & 3,8 \\
Cabelereira & 1 & 1,9 \\
Caixa Operadora & 1 & 1,9 \\
Caixa Supermercado & 1 & 1,9 \\
Camareira & 1 & 1,9 \\
Comerciante & 1 & 1,9 \\
Comerciária & 1 & 1,9 \\
Costureira & 2 & 3,8 \\
Desempregada & 4 & 7,7 \\
Do Lar & 1 & 1,9 \\
Educadora Assistencial & 1 & 1,9 \\
Emissora de passagem & 1 & 1,9 \\
& & continua
\end{tabular}


Atividade Profissional da vítima (continuação)

\begin{tabular}{lcc}
\hline & Frequência & Porcentual \\
\hline Estudante & 2 & 3,8 \\
Eventos & 1 & 1,9 \\
Gari & 1 & 1,9 \\
Manicure & 1 & 1,9 \\
Monitora & 1 & 1,9 \\
Operadora de Telemarketing & 1 & 1,9 \\
Padeira & 1 & 1,9 \\
Pedagoga & 1 & 1,9 \\
Porteiro & 1 & 1,9 \\
Recepcionista & 1 & 1,9 \\
Repositora & 1 & 1,9 \\
Secretária & 2 & 3,8 \\
Serviços Gerais & 3 & 5,8 \\
Servidor Público & 1 & 1,9 \\
Técnica Enfermagem & 1 & 1,9 \\
Técnica Odontológica & 1 & 1,9 \\
Vendedora & 4 & 7,7 \\
Total & 52 & 100,0 \\
\hline & & \\
\hline & 1 & 1 \\
\hline
\end{tabular}

\section{Ocupação agressor}

\begin{tabular}{|c|c|c|c|}
\hline & & Frequência & Porcentual \\
\hline & Advogado & 1 & 1,9 \\
\hline & Aposentado & 1 & 1,9 \\
\hline & Autônomo & 5 & 9,6 \\
\hline & Chefe limpeza & 1 & 1,9 \\
\hline & Chefe tratamento piso & 1 & 1,9 \\
\hline & Cobrador ônibus & 1 & 1,9 \\
\hline & Conferente & 1 & 1,9 \\
\hline & Desempregado & 5 & 9,6 \\
\hline & Eletricista & 1 & 1,9 \\
\hline & Empresário & 2 & 3,8 \\
\hline & Ferreiro & 2 & 3,8 \\
\hline & Gerente de trailer & 1 & 1,9 \\
\hline & Lavador de carros & 1 & 1,9 \\
\hline & Mecânico & 1 & 1,9 \\
\hline & Metalúrgico & 1 & 1,9 \\
\hline & Motoboy & 1 & 1,9 \\
\hline Válido & Motorista & 2 & 3,8 \\
\hline & Oficial Judiciário & 1 & 1,9 \\
\hline & Pedreiro & 4 & 7,7 \\
\hline & Pintor & 1 & 1,9 \\
\hline & Pintor/Chapeador & 1 & 1,9 \\
\hline & Porteiro & 3 & 5,8 \\
\hline & Porteiro Prédio & 1 & 1,9 \\
\hline & Preso condicional & 1 & 1,9 \\
\hline & Projetista móveis & 1 & 1,9 \\
\hline & Promotor de Vendas & 1 & 1,9 \\
\hline & Representante Comercial & 1 & 1,9 \\
\hline & Segurança & 1 & 1,9 \\
\hline & Servente & 1 & 1,9 \\
\hline & Servente de obras & 1 & 1,9 \\
\hline & Serviços Gerais & 3 & 5,8 \\
\hline & Vendedor & 1 & 1,9 \\
\hline & Zelador & 1 & 1,9 \\
\hline & Total & 52 & 100,0 \\
\hline
\end{tabular}

Os dados colhidos permitiram traçar o perfil das vítimas. No que respeita à idade, concentram-se em duas faixas etárias: de 21 a 30 anos $(28,8 \%)$ e 31 a 40 anos (50\%). As mais jovens, até 20 anos, correspondem a $9,6 \%$, enquanto a faixa etária de 41 a 50 anos alcança $9,6 \%$. As mulheres acima de 51 anos constituem a minoria, apenas $1,9 \%$.

Elas se declaram solteiras $(82,7 \%)$, casadas $(5,8 \%)$, divorciadas $(7,7 \%)$ em união estável $(1,9 \%)$ e separadas $(1,9 \%)$.

A maioria é de cor branca $(65,4 \%)$, as demais são negras $(25,0 \%)$ e pardas $(9,6 \%)$.

Naturais da capital $(73,1 \%)$, do interior do Rio Grande do Sul $(23,1 \%)$ e de outros estados $(3,8 \%)$.

Quanto ao quesito escolaridade, o maior número é de pessoas que concluíram o ensino médio $(38,5 \%)$, seguidas por aquelas que afirmaram ter feito apenas o ensino fundamental incompleto $(17,3 \%)$ e completo $(17,3 \%)$, o ensino médio incompleto $(15,4 \%)$. Aquelas que ingressaram no ensino superior são minoria, 7,7\% não concluiu o curso e apenas $3,8 \%$ concluiu curso superior.

O percentual de trabalhadoras com renda própria alcança $86,5 \%$, somente $13,5 \%$ declararam não ter renda própria. Os valores auferidos não são altos. $\mathrm{Na}$ primeira faixa - até R $\$ 800,00$ - encontram-se 42,3\% das entrevistadas, sendo que $26,9 \%$ encontram-se na segunda faixa de renda - de R $\$ 801,00$ a $\mathrm{R} \$ 1.200,00$. Entre R\$1.601,00 e R\$2.000,00, apenas 7,7\% das pessoas ouvidas. O restante está dividido entre as faixas de $\mathrm{R} \$ 1.201,00$ a $\mathrm{R} \$ 1.600,00(5,8 \%)$ e acima de $\mathrm{R} \$ 2.001,00$, encontram-se $3,8 \%$ das trabalhadoras.

As ocupações são diversas e variadas, predominando as vendedoras $(7,7 \%)$ seguidas pelas que se dedicam aos serviços gerais $(5,8 \%)$, auxiliares administrativas $(3,8 \%)$, balconistas $(3,8 \%)$, costureiras $(3,8 \%)$, estudantes $(3,8 \%)$, secretárias $(3,8 \%)$. As desempregadas alcançam o percentual de 7,7\%.

No que respeita ao perfil do agressor, são estes: companheiros $(65,4 \%)$, ex-companheiros $(17,3 \%)$, namorados $(9,6 \%)$ e por último maridos $(7,7 \%)$. Predominam os indivíduos de 21a 30 anos (30,8\%) e de 31 a 40 anos (30,8\%). Em seguida, vêm os agressores de 41 a 50 anos $(26,9 \%)$ e os mais jovens, até 20 anos $(1,9 \%)$.

Os níveis de escolaridade encontrados não são altos. A maior concentração está no ensino fundamental incompleto $(36,5 \%)$, seguindo-se o ensino médio completo $(28,8 \%)$, o ensino fundamental completo $(19,2 \%)$, o ensino superior incompleto $(7,7 \%)$ o ensino médio incompleto $(5,8 \%)$ e finalmente o ensino superior completo (apenas 1,9\%). 
Predominam os agressores que auferem renda mensal entre $\mathrm{R} \$ 801,00$ e $\mathrm{R} \$ 1.200,00$ (26,9\%). Em segundo lugar, os de renda mais alta, acima de $\mathrm{R} \$ 2.001,00$ (21,2\%). Os demais acham-se assim distribuídos: de $\mathrm{R} \$ 1.601,00$ a $\mathrm{R} \$ 2.000,00(11,5 \%)$ e até $\mathrm{R} \$ 800,00(7,7 \%)$. Um percentual alto $(25,0 \%)$ das mulheres não soube informar a renda do agressor.

As profissões dos agressores são as mais diversas. Citam-se as mais encontradas: autônomo (9,6\%), pedreiro $(7,7 \%)$, porteiro $(5,8 \%)$, serviços gerais $(5,8 \%)$, motorista $(3,8 \%)$, empresário $(3,8 \%)$, ferreiro (3,8\%). Os desempregados constituem $9,6 \%$ do grupo.

Com relação à violência sofrida, informam as vítimas que ela é física e psicológica $(57,7 \%)$, somente psicológica $(30,8 \%)$ e somente física $(11,5 \%)$.

As vítimas sofreram violência de 1 a 3 vezes $(30,8 \%)$, mais de 11 vezes $(30,8 \%)$, de 7 a 10 vezes $(21,2 \%)$ e de 4 a 6 vezes $(17,3 \%)$. E há quanto tempo? Há mais de 25 meses (38,5\%), de 7 a 12 meses $(23,1 \%)$, até 6 meses $(21,2 \%)$, de 19 a 24 meses $(15,4 \%)$ e de 13 a 18 meses $(1,9 \%)$.

Interrogadas a respeito do motivo da agressão, as vítimas apontaram para conflitos conjugais diversos (55,8\%), álcool (26,9\%) e drogas (17,3\%). Acrescentese que estes conflitos conjugais diversos abarcam múltiplas razões, como ciúmes, traição, término do relacionamento, transtornos e surtos de doença mental, mentiras, disputas por pensão alimentícia, estresse no trabalho, desemprego do agressor, superendividamento, débitos trabalhistas (trabalhou em empresa do agressor), esterilidade da mulher, divergências quanto a gastos. Em alguns casos, o álcool vem associado ao consumo de drogas (cocaína, crack, maconha); em outros, o ciúme é apontado como a motivação para as agressões, conjuntamente com o consumo de álcool.

Perguntadas a respeito da situação financeira da família à época da agressão, responderam que era boa $(46,2 \%)$, regular $(42,3 \%)$, ruim $(9,6 \%)$ e ótima (somente 1,9\%).

Indagadas se o ofensor estava afetado pela situação financeira, a maioria respondeu que não $(78,8 \%)$, sendo que as restantes admitiram que $\operatorname{sim}(21,2 \%)$.

A este ponto da reflexão, cumpre mencionar a pesquisa realizada por Isaac Sabbá Guimarães, na Comarca de Balneário de Camboriú, Santa Catarina, "envolvendo situações que por lei são caracterizadas como de violência doméstica" 28 .

As entrevistas foram realizadas pela Assistente Social do Ministério Público, feita exclusivamente nas dependências do forum local, nas datas de audiências judiciais, ponto de contato com a pesquisa ora descrita, por nós realizada em Porto Alegre.

Observa o autor:
... constata-se que as circunstâncias de baixa escolaridade, baixo rendimento, para além da dependência emocional e financeira das vítimas, são indicativos que se entrelaçam ao fenômeno da violência praticada contra mulheres ${ }^{29}$.

Sobre as causas da violência:

Nas entrevistas levadas a efeito, a pesquisadora também observou que os vínculos conjugais fragilizados, os problemas de saúde (incluindo aí a dependência química em relação a drogas e álcool), imbricam-se com a violência... a violência contra a mulher ou doméstica brota numa circunstância de adversidades, onde se identificam problemas de relacionamento, financeiros e de saúde ${ }^{30}$.

$\mathrm{Na}$ pesquisa empreendida em Camboriú, foram ouvidos os agressores sobre a motivação da violência, evidenciando-se que os problemas de ordem social (50\%), seguidos pelos de saúde (22\%) e econômicofinanceiro (10\%) apresentam-se como os principais ${ }^{31}$.

\section{CONCLUSÃO}

Através do presente estudo pretendeu-se desvendar a relação entre dois problemas relevantes para a sociedade, o superendividamento e a violência doméstica. Fenômenos complexos que se entrecruzam na vida das pessoas e das famílias. Uma primeira observação que se impõe é a de que se faz necessário encarar e investigar mais detidamente os impactos familiares derivados do superendividamento.

$\mathrm{O}$ crédito em si mesmo não pode ser considerado como um mal. Contudo, o que preocupa é a sua expansão e facilitação sem critérios ou algum tipo de consideração para com o consumidor que o toma.

O superendividamento, reconhecido como um fenômeno social e jurídico, exige uma saída por toda sorte de consequências que provoca, quer do ponto de vista individual, quer do ponto de vista da família do superendividado.

Não é só o superendividado que sofre com o fato, mas toda a sua teia de relações familiares vem a ser abalada. Assim assinala a doutrina mencionada no corpo deste trabalho. Muitos aspectos da vida familiar em seu conjunto e dos seus integrantes individualmente e dos filhos são atingidos. No interior dos lares, desenrolam-se dramas e tragédias.

Não obstante todos os progressos científicos, tecnológicos e legais, presentes na sociedade atual, a violência contra a mulher continua a existir e a desafiar a todos. A Lei Maria da Penha teve por objetivo estabelecer mecanismos para coibir a 
violência doméstica e familiar contra a mulher. É uma lei eficaz, que veio para ficar e contribuir para o enfrentamento da questão da violência doméstica e familiar. As dificuldades financeiras, dentre elas o superendividamento, contribuem para a violência concretizada contra companheiras, esposas, ex-esposas e ex-companheiras. Se é verdade que as motivações do agressor são múltiplas, multifacetadas e combinadas, parece evidente que os fenômenos superendividamento e violência se entrelaçam.

As disputas que envolvem questão financeira entre os casais, aliados a outros fatores, despontam como causas, alimentando a existência do perverso mecanismo da violência. O consumo do álcool e da droga individualmente emerge como os motivos apontados com maior precisão. Mas, a maioria das entrevistadas indicou situações que foram agrupadas como conflitos conjugais diversos, os quais, isolados ou combinados entre si, deram origem às práticas de violência. Consultando-se as respostas dadas à pergunta a respeito da situação financeira da família, a maioria das vítimas afirmou que era regular $(42,3 \%)$ e ruim $(9,6 \%)$. Interrogadas se o agressor achava-se afetado pela situação financeira, $21,2 \%$ afirmaram que sim. Estes dois itens contribuem para o esclarecimento da relação superendividamento e violência doméstica.

O cruzamento do superendividamento e da violência doméstica faz ver que há muitos aspectos a serem estudados. Por exemplo, merecem um exame mais acurado as repercussões do superendividamento na Previdência Social e no Sistema Único de Saúde. Esta observação se estende também à violência. As motivações que influem na prática da violência também exigem a atenção dos especialistas, pois só assim se poderá enfrentar e reprimir tal ilícito e proteger devidamente a mulher.

\section{REFERÊNCIAS}

BIANCHINI, Alice. Lei Maria da Penha: Lei 11.340/2006; aspectos assistenciais, protetivos e criminais da violência de gênero. São Paulo: Saraiva, 2013.
FRADE, Catarina; MAGALHÃES, Sara. Sobreendividamento, a outra face do crédito. In: MARQUES, Cláudia Lima; CAVALLAZZI Rosângela Lunardelli (Coord.). Direitos do consumidor endividado: superendividamento e crédito. São Paulo: Revista dos Tribunais, 2006. GUIMARÃES, Isaac Sabbá; MOREIRA, Rômulo de Andrade. $A$ Lei Maria da Penha: aspectos criminológicos, de política criminal e do procedimento penal. 2. ed. Curitiba: Juruá, 2011.

LIMA, Clarissa Costa de; BERTONCELLO, Karen Rick Danilevicz. Superendividamento aplicado: aspectos doutrinários e experiência no Poder Judiciário. Rio de Janeiro: GZ Editora, 2011.

MARQUES, Cláudia Lima. Sugestões para uma lei sobre o tratamento do superendividamento de pessoas físicas em contratos de crédito ao consumo: proposições com base em pesquisa empírica de 100 casos no Rio Grande do Sul. In: MARQUES, Cláudia Lima; CAVALLAZZI Rosângela Lunardelli (Coord.). Direitos do consumidor endividado: superendividamento e crédito. São Paulo: Revista dos Tribunais, 2006.

MIRAGEM, Bruno. Curso de direito do consumidor. 4. ed. rev., atual. e ampl. São Paulo: Revista dos Tribunais, 2013.

MOREIRA, Milene. Violência doméstica e familiar: a Lei Maria da Penha e o princípio da igualdade e a dignidade da pessoa humana. Porto Alegre: Núria Fabris Ed., 2011.

MONTLIBERT, Christian de. Les surendettés ou les déchus du monde economique. In: Regards sociologiques, n. 32, 2006.

SAMPAIO, Marília de Ávila e Silva. A garantia dos direitos de personalidade, a proteção do devedor superendividado no Brasil e a proposta de alteração do CDC. In: ANDRIGHI, Fátima Nancy (Coord.). Responsabilidade civil e inadimplemento no direito brasileiro. São Paulo: Atlas, 2014.

SCHMIDT NETO, André. Revisão dos contratos com base no superendividamento. Curitiba: Juruá, 2012.

SEVERINO, Antônio Joaquim. Metodologia do trabalho científico. 23. ed. rev. e atual. São Paulo: Cortez, 2007.

TOMAZETTE, Marlon. Disciplina dos juros moratórios e remuneratórios no direito brasileiro. In: ANDRIGHI, Fátima Nancy (Coord.). Responsabilidade civil e inadimplemento no direito brasileiro. São Paulo: Atlas, 2014.

\section{Outras fontes:}

Brasileiro com dívida tem mais doença que o europeu. Caderno Reportagem O Sul. Porto Alegre, 01 mar. 2014.

Crédito no Brasil aumenta 500\% nos últimos dez anos. Disponível em: <http://exame.abril.com.br/noticia/volume de crédito no Brasil aumenta 500 nos ultim...>. Acesso em: 27 jan. 2014.

RELATÓRIO FINAL da Comissão Parlamentar Mista de Inquérito. Brasília, DF: Senado Federal, 2013.

RELATÓRIO FINAL: Violência contra a mulher e acesso à Justiça. Estudo comparativo sobre a aplicação da Lei Maria Penha em cinco capitais. Coordenação geral CEPIA - Cidadania, Estudos, Pesquisa, Informação e Ação. Disponível em: <http://www.cepia. org.br/pesquisa>. Acesso em: 12 fev. 2014.

\section{NOTAS}

${ }^{1}$ Disponível em: <http://exame.abril.com.br/noticia/volume de crédito no Brasil aumenta 500 nos ultim... > Acesso em: 27/01/2014.

2 MIRAGEM, Bruno. Curso de direito do consumidor. 4. ed.rev., atual. e ampl. São Paulo: Revista dos Tribunais, 2013. p. 380.

${ }^{3}$ MIRAGEM, Bruno. Op. cit., p. 380.

${ }^{4}$ MIRAGEM, Bruno. Op. cit., p. 383.

5 SAMPAIO, Marília de Ávila e Silva. A garantia dos direitos de personalidade, a proteção do devedor superendividado no Brasil e a proposta de alteração do CDC. In: ANDRIGHI, Fátima Nancy (Coord.).
Responsabilidade civil e inadimplemento no direito brasileiro. São Paulo: Atlas, 2014, p. 222.

${ }^{6}$ Entrevista à Agência Brasil. Disponível em: <http://agenciabrasil.ebc. com.br/noticia/2010-12-03/mercado de credito ao consumo-s...>. Acesso em: 27 jul. 2013.

${ }^{7}$ MARQUES, Cláudia Lima. Sugestões para uma lei sobre o tratamento do superendividamento de pessoas físicas em contratos de crédito ao consumo: proposições com base em pesquisa empírica de 100 casos no Rio Grande do Sul. In: MARQUES, Cláudia Lima; CAVALLAZZI, Rosângela Lunardelli (Coord.). Direitos do consumidor endividado: superendividamento e crédito. São Paulo: Revista dos tribunais, 2006, p. 256. 
${ }^{8}$ MARQUES, Cláudia Lima. Op. cit., p. 256-257.

${ }^{9}$ MARQUES, Cláudia Lima. Op. cit., p. 258-259.

${ }^{10}$ LIMA, Clarissa Costa de e BERTONCELLO, Karen Rick Danilevicz. Superendividamento aplicado: aspectos doutrinários e experiência no Poder Judiciário. Rio de Janeiro: GZ Editora, 2011, p. 27, 247, 317 e 318.

${ }^{11}$ SCHMIDT NETO, André. Revisão dos contratos com base no superendividamento. Curitiba: Juruá, 2012, p. 218.

${ }^{12}$ SAMPAIO, Marília de Ávila e Silva. Op. cit., p. 224.

13 FRADE, Catarina e MAGALHÃES, Sara. Sobreendividamento, a outra face do crédito. In: Direitos do consumidor endividado: superendividamento e crédito. Op. cit., p. 23-43.

14 FRADE, Catarina e MAGALHÃES, Sara. Sobreendividamento, a outra face do crédito. Op. cit., p. 26-33.

15 FRADE, Catarina e MAGALHÃES, Sara. Sobreendividamento, a outra face do crédito. Op. cit., p. 27.

16 FRADE, Catarina e MAGALHÃES, Sara. Sobreendividamento, a outra face do crédito, Op. cit., p. 27.

17 FRADE, Catarina e MAGALHÃES, Sara. Sobreendividamento, a outra face do crédito. Op. cit., p. 28.

18 FRADE, Catarina e MAGALHÃES, Sara. Sobreendividamento, a outra face do crédito. Op. cit., p. 30.
19 FRADE, Catarina e MAGALHÃES, Sara. Sobreendividamento, a outra face do crédito. Op. cit., p. 30

${ }^{20}$ FRADE, Catarina e MAGALHÃES, Sara. Sobreendividamento, a outra face do crédito. Op. cit., p. 32.

${ }^{21}$ MONTLIBERT, Christian de. Les surendettés ou les déchus du monde economique. In: Regards sociologiques, n. 32, 2006, p. 127-128.

22 Caderno de Reportagem, O Sul, 01 mar. 2014, p. 2.

${ }^{23}$ Relatório final da Comissão Parlamentar Mista de Inquérito, Apresentação, p. 3.

${ }^{24}$ Relatório final da Comissão Parlamentar Mista de Inquérito, Apresentação, p. 3.

25 SEVERINO, Antônio Joaquim. Metodologia do trabalho científico. 23. ed. rev. e atual. São Paulo: Cortez, 2007. p. 123.

26 SEVERINO, Antônio Joaquim. Op. cit., p. 103.

${ }^{27}$ SEVERINO, Antônio Joaquim. Op. cit., p. 125.

${ }^{28}$ GUIMARÃES, Isaac Sabbá; Moreira, Rômulo de Andrade. A Lei Maria da Penha: aspectos criminológicos, de política criminal e do procedimento penal. 2. ed. Curitiba: Juruá, 2011, p. 89-110.

${ }^{29}$ GUIMARÃES, Isaac Sabbá. Op. cit., p. 105.

${ }^{30}$ GUIMARÃES, Isaac Sabbá. Op. cit., p. 105.

${ }^{31}$ GUIMARÃES, Isaac Sabbá. Op. cit., p. 109. 